\title{
Hières-sur-Amby - Marignieu, impasse des Ridolières
}

$n^{\circ} 2211092$

Stéphane Bleu

\section{(2) OpenEdition}

Journals

Édition électronique

URL : http://journals.openedition.org/adlfi/15080

ISSN : 2114-0502

Éditeur

Ministère de la culture

\section{Référence électronique}

Stéphane Bleu, « Hières-sur-Amby - Marignieu, impasse des Ridolières », ADLFI. Archéologie de la

France - Informations [En ligne], Rhône-Alpes, mis en ligne le 30 juillet 2015, consulté le 19 avril 2019. URL : http://journals.openedition.org/adlfi/15080

Ce document a été généré automatiquement le 19 avril 2019

(c) Ministère de la Culture et de la Communication, CNRS 


\section{Hières-sur-Amby - Marignieu, impasse des Ridolières}

$\mathrm{n}^{\circ} 2211092$

\section{Stéphane Bleu}

Lien Atlas (MCC) :

http://atlas.patrimoines.culture.fr/atlas/trunk/index.php?

ap_theme=DOM_2.01.02\&ap_bbox=5.267;45.780;5.316;45.822

1 Un diagnostic archéologique a été réalisé à l'emplacement supposé d'une importante villa romaine. La parcelle concernée (AB 297) est implantée sur des affleurements de moraines würmiennes Gx6 (stades indifférenciés) résiduels déposés à la base du versant septentrional du plateau calcaire.

2 Trois sondages ont été réalisés sur l'ensemble de l'emprise et aucun indice d'une fréquentation humaine ancienne n'a été observé.

\section{INDEX}

Index géographique : Rhône-Alpes, Isère (38), Hières-sur-Amby operation Opération préventive de diagnostic (OPD) 


\section{AUTEURS}

STÉPHANE BLEU

Inrap 